\title{
An Interview with Roddy Doyle
}

\author{
Burcu Gülüm Tekin
}

Universidad de Granada, España

Copyright (c) 2014 by Burcu Gülüm Tekin. This text may be archived and redistributed both in electronic form and in hard copy, provided that the author and journal are properly cited and no fee is charged for access.

\begin{abstract}
In this interview, Roddy Doyle, one of the most popular contemporary writers in Ireland, provides insightful comments on crucial aspects of his writing career. Doyle speaks about the beginning of his literary adventure, the creative process of his work, and his artistic influences, as well as his feeling of pride in being a native Dubliner. Furthermore, he addresses his experience of the Celtic Tiger era in Ireland and the multicultural reality of the country in the late 1990s. Doyle's detailed discussion of the female characters in his work is one of the most intriguing parts of the interview. He also gives hints about his latest novel The Guts (2013) and talks about the shift in theme, to the middle-age crisis in men, in his recent work: The Bullfighting (2011), Two Pints (2012), and The Guts (2013). His ideas about the filmic adaptations of his work, his favourite writers and his favourite fictional female characters are other inspiring points of the interview. The interview closes with Doyle's characterization of the Post-Celtic Tiger period in Ireland and his views about the shifting portraits of Irish men and women.
\end{abstract}

Key Words. Roddy Doyle, contemporary Irish literature, Celtic Tiger era, Post-Celtic Tiger period, female characters in Roddy Doyle's Work, middle-age crisis in men.

Resumen. En esta entrevista, Roddy Doyle, uno de los escritores más relevantes de la Irlanda contemporánea, aborda aspectos cruciales en su carrera literaria, tales como los inicios de su aventura como escritor, el proceso creativo de su obra, sus influencias artísticas, y su sentimiento de orgullo de ser dublinés. Doyle también habla sobre su visión de la Irlanda del Tigre Celta, la posterior recesión del país y la realidad multicultural que se observa en la actualidad. Por primera vez, el autor reflexiona sobre el cambio temático que ha experimentado su obra más reciente, y cómo la crisis de la mediana edad en los hombres es el eje central de Bullfighting (2011), Two Pints (2012), y The Guts (2013). Otros aspectos mencionados en esta entrevista son las adaptaciones cinematográficas de su obra, sus escritores favoritos, sus personajes femeninos favoritos de ficción, y cómo las mujeres aparecen retratadas en su obra.

Palabras Clave. Roddy Doyle, literatura irlandesa contemporánea, la Irlanda del Tigre Celta, personajes femeninos en la obra de Roddy Doyle, crisis de mediana edad en los hombres.

BGT: Thank you very much for accepting my interview request. I have read that you were teaching English before you dedicated yourself to being a full-time writer. When and how did your writing adventure start? How has your literary background affected your writing?

RD: I started writing when I was a teenager ... when I started reading. I have always read a lot.
Always, all my life I was a reader. I think I was in school for three years before I found out how to read. I was taught by my mother. Once I could read, I never stopped, particularly in my teenage years, when I realized that people had written these books and maybe they had written more books. I remember when I read Catch 22 by Joseph Heller I would have been 16, and at that time he hadn't written any more books and 
I remember being a little bit heartbroken that there was only one book by him at the time. I remember searching for other books by other people but at the back of my mind I thought: 'well, I would like to do that; I would like to try it'. There was no creative writing school at the time, not until the late 1970s. I went to college, and became a teacher almost immediately, then I started teaching because then I had free time: I had no family so I had a lot of holidays in the summer.

BGT: I'm writing my PhD on the female characters of your work and am interested in their representation. I would like to address this particular aspect, if you do not mind. So far, your work has introduced many fictional female figures. We also hear about the real life characters in your nonfiction volume Rory \& Ita, which is about your parents. I have found it highly interesting, in particular those parts narrated by your mother. I wonder to what extent your fiction is influenced by the women in your life? In other words are the female characters in your work inspired by actual women?

RD: No, not directly. So you're asking me do I know Paula Spencer, for example. No, I don't. If you're asking me, do I know Jimmy Rabitte, I have a book [The Guts] coming out soon from The Commitments, and now Jimmy is a middleaged man - he is 48 years old and he has a wife he has been married to for twenty - twentyseven years and do I know her? No. In the very beginning, if we go to, say The Commitments, my first novel, the young women in that book are inspired by the young women and the girls I used to teach. I can't say directly that this one is a fictional character and that one a real girl, now in their late forties. It was their energy, their wit, their humour, the way that they faced the world, which is in a way very un-Irish; they were supposed to be devout Catholics, quiet girls who did what they were told but actually they were not; they were much more lively and more energetic so when I wrote The Commitments they were in the back of my mind. I was still a teacher when I wrote The Commitments. Then, when I wrote The Snapper, it was purely fictional actually; not inspired by anything in my own family or anything else. Pregnancy is such a universal story. It's a very short book but it took three years to write, to capture the main character's life, most obviously the biology, the pregnancy. I have been a father three times but the biology was always going to be foreign to me. I was the father after all and not the mother: no amount of empathy or emotions is going to get you closer to it. There was a certain amount of reading but mostly it was choosing the words that actually worked to get the woman's voice. It was a bit of guesswork there because how can you really tell? Almost inevitably when it comes to the something that I don't have direct experience of, whether it's violence in this case or being a member of a band for example, which I've never been, being involved in historical events when I wasn't even born; so when it comes to experience outside my own, I tend to write too much and then take a lot of it back and it's the exact same as with creating Sharon Rabitte or the first of the people to occupy a book. I wrote way too much, twice as much as is actually in the book and I just cut it away until that moment. That's how I get to know any characters really, but particularly the female characters. I have no real idea at first, very vague, I write too much, get to know them, take most of it away. The most extreme one was The Woman Who Walked into Doors. When I was describing her reaction to the violence, I have no direct experience of domestic violence or any other sort of violence and very little experience of physical pain but I used it to describe hers. I changed my physical pain experience, took away a lot of it, and ended up with The Woman Who Walked into Doors who was in the fiction.

BGT: Do you think that Paula Spencer (in The Woman Who Walked into Doors) or Sharon (in The Snapper) somehow subvert traditional notions of Irish femininity? Sharon, for instance, gets pregnant outside wedlock...

RD: Yes, but that was very common, very common in the 1980s in Ireland so it wasn't written about, I suppose. I started writing that book in late 1986. It wasn't published until 1990. What I did was, I think maybe for the first time, to present it as something that wasn't shameful and that wasn't to be hidden. That was all - the only drama in the story to an extent is the father. It's a common story so I 
wasn't doing anything revolutionary there. I was actually, in a way, giving a fictional shape to what I was seeing every day, there is nothing more. In a way all fictional characters should subvert, if they are going to be alive on the page. They have to be more than real including the naturalistic way - I don't buy into that. I am quite happy with literary movements such as naturalism and realism, but you know all writing is somehow heightened. All characters are somehow more than their human character because you home in on their lives in 200-300 pages or in the case of writing the novel, two or three years of your life and you pick and choose the moments that are revealed to the reader. It's all heightened I think, if you like; in The Woman Who Walked into Doors, I got in behind the door. I gave voice to this woman who ordinarily wouldn't have been there due to many conscious decisions of society ignoring her. The opportunity sometimes in fiction is to put on paper people who aren't often on paper. She was a case in point but it was nothing. In some ways obviously she is not typical but she is a fictional character and she has her own book; in fact she has two books. In the way she thinks, the way she manages or doesn't manage her life, the way she reacts to her husband and children, I would imagine they are very typical of anybody.

BGT: What comes first into your mind in the creation process of a literary product: $A$ character's physical or/and mental features or the plot itself?

RD: Almost never the physical features. I'm not really interested. There is a lot of physical detail in The Snapper but only as Sharon's body changes during the pregnancy. I have no recollection if she was tall, if she had dark hair, what colour her eyes were. I don't think eye colour comes into it, at all. Physical features don't really matter -even in The Commitments with three young women who the young men were obviously attracted to - I don't know if I have mentioned hair colour or eye colour or anything like that, the usual clichés, so I don't know what Paula Spencer looks like. It's only what she tells us.

BGT: I have asked that because in some novels I feel as if you're visualizing the characters and the dialogues stand as if they are from a movie. Also, many of your literary works have been adapted to the screen.

RD: Yes, they were novels first.

\section{BGT: Yes, I know.}

RD: That's the reader... That's the reader at work, not me. I firmly believe in leaving gaps for the reader. The reader is active, because I' $m$ a reader myself and I'm actively involved. I'm not a passive recipient of the world; I respond. I'd often be in the process of having read a book when there is no literal description of a character but I have a very strong sense of what they're like. That's the words; they somehow work a chemical reaction in my brain, my mind or whatever so that's what my job is: to put the words as exactly as I want them on the page and then the reader responds in that way; to keep the dialogues lively, keep the scenes real, to put the human being together. I suppose I don't listen to much drama on the radio but I often notice that if I find myself enjoying it, I begin to see the characters. It's my own version so your idea what Paula Spencer looks like, that's your idea, not mine. [Smiles]

BGT: Speaking about female characters who have been through domestic violence $I$ also like Paddy Clarke $\mathrm{Ha} \mathrm{Ha} \mathrm{Ha}$. In a way, it is through Paddy's narration that we find out that his mother is exposed to domestic violence; we do not hear her voice often nor do we learn much about her. Is it a deliberate silence, I would like to ask?

RD: It's a ten year old boy's outlook. It's quite late into the book where he comes across this horrible notion that his parents' marriage is breaking up and there is a doubt as to whether there is physical violence there. I haven't read that book since I wrote it so it was long time ago. There might be the throwing of things, the stomping at the table, thumping on the table but I don't think that there is any overt proof that there is any physical violence. I probably would have thought not. I don't know; maybe my memory of the book towards the end is a bit sketchy but it had to be a ten year old boy's view. His parents are going through a breakup and that's plain but it doesn't become plain to him until quite late. They are sensitive enough 
and naive enough to hope that their arguments can't be heard by their children. Paddy, of course, is awake on the stairs, hoping that by staying awake it will stop all these little superstitious things that we carry with us throughout our lives. If I stop looking, the bus will come; you know that type of thing. I don't think that ever stops. I suppose it's particularly alive in a 10-year-old boy. I was a slave to the notion of Paddy as a 10-year-old boy. I couldn't ignore the insight that you would get from that he is a 10-year-old boy. It's a horrible experience to live. His mother is always is up there. [Showing high up with his hand] She is there; up there. You know everything is up there for a 10-year-old because they are small so then he misses a lot. He has no idea about a break-up and that was important to the book and I couldn't go "that happened to me twenty years ago and my parents just...". I hate that perspective in hindsight. "But I was only a 10year-old boy then, now I know more". That book works because he was a 10 -year-old boy not a 30-year-old man looking back at the time when he was there so that immediacy means that Paddy's view is very limited. Sometimes I would imagine that a marriage could explode or a relationship could explode. It's only years later when the two people involved understand life; years, hindsight. We all become very wise so Paddy is actually trying to keep up.

BGT: What motivated you to write about domestic violence in The Woman Who Walked into Doors and Paula Spencer?

RD: I had written three novels between The Snapper and The Van. Particularly with The Snapper, there is not much of the family in The Commitments. The Snapper is all about family and The Van as well. I had written about the one family, The Rabitte family, an emotionally successful family. The baby born in The Snapper is lucky to be born in that house: very crowded and very loud. I think, emotionally lucky, that baby will be loved. I didn't want to write another book about the same family because I thought it would become a bit shrill. The question I would be asking myself is "I am saying that all families are like this? Because what about the unsuccessful?" As a result, I started to imagine not necessarily literally the next door neighbours but people on the same street whose emotional life isn't as successful. Besides, I was invited by the BBC to write a television series but it was an open invitation; I could write anything at all. I thought I was going to meet with the producers from the BBC. I was on the DART, the train, on the way to the city centre and I began to imagine a four part series and each part was told from the point of view of a different character. I didn't have names but I thought Paula and her husband, son, daughter, wife, father: one-twothree-four. I put that idea to them and they said "yes" so I wrote this series called Family, which was made by the BBC and broadcast in 1994. While I was writing the last episode which is Paula's episode, after she has thrown her husband out, I began to wonder about the rest of her life. What had happened before and what happens after, like a lot of people who witnessed a marital breakup and have often wondered, from our point of view perhaps, "why it happened that that really lovely woman married that creep" or the other way around, "how that really nice, decent man married that monster". You sometimes wonder ...; it's a common question. Joe Jackson has got a great song "Is She Really Going Out with Him?" I mean it's not necessarily about violence; it's about jealousy, as well, sometimes envy. I began to wonder about what she saw in this man seventeen years before the moment where she throws him out. At what point did he become violent? Did he know why or did he never know why? Did he carry that into the marriage? Was alcohol involved? How did she become much older than she should be in her years and then what happens afterwards? Then, I began to piece together this and it becomes The Woman Who Walked into Doors. It's almost an unusual one. The Commitments was a novel and a film; The Snapper was a novel and a film; The Van was a novel and a film. Paula, in The Woman Who Walked into Doors was a novel but before that it was a part of a television series. It was an unusual enough outline. I can't think of many examples where the novel has been inspired by the writing of something for television.

BGT: I think Paula Spencer is a perfect novel about a heroine rising from her ashes. Paula unconsciously employs a strategy of 
psychological recovery which is writing. Do you personally believe in this strategy? Do you think that writing can have a therapeutic function?

RD: I don't know to be honest. I don't think it should ever be presented as therapy. If it works that way then, great! However, I think that if the writing is to have any strength at all it should be presented as writing; that is to say if you get any lift to your self esteem or you get any clarity by writing, great. If you want to use your direct experience, great. I've come across people who have written about their direct experience but they have written badly; but they seem to think that because it's their direct experience that somehow it's valid as a piece of writing, which it isn't. I'm nervous of writing as therapy but I could see why keeping a diary and trying to work out what happened could work. I think that the conceit, the trick of The Woman Who Walked into Doors is that I imagined when I started a woman at a table writing into a copybook. It may have started with a sense of therapy of writing but actually she is a very good writer and she begins to realize how you do it. Additionally, she edits the book and then she plays with the reader actually because things aren't revealed until quite late. When I started it, the first draft I imagined her being an enthusiastic, being a very intelligent woman but kind of unschooled. You know what I mean by unschooled: not particularly well-educated, like a lot of people of her generation, working class women and men of her generation. Her particular intelligence might not be recognized by the education system or by the teacher at the front of the room. She would have left school feeling slightly, officially stupid. Right? She wouldn't have read much in terms of fiction; her life didn't go smoothly. If she did, it might have been a few Maeve Binchy books, good books but conventionally told. I felt that she could have started with her childhood and worked into her teenage years, but I thought that actually that would be boring. That would be very boring regardless of her realism and how well she does it. As a result, I decided to break the story into three parts: her early life, her recent history and then her present and I'd tell them in three parallel lines, three parallel tracks.
That's why it works, I think, because if I'd told it in a more conventional way I don't think it would have worked. It would have been wellintentioned, and might not be bad but it would have been very boring. I gave her more editorial skill in a way, because you have to fall into the trap of thinking that she is the one who is writing the book. Paddy Clarke obviously as well. He is a better writer than most ten year olds, I think and that's how that particular book worked. Is it therapeutic? I don't know. The simple reason is that she's a fictional character so it doesn't seem therapeutic. Does she feel better? How can you tell? She doesn't exist outside the pages of the book.

BGT: I prefer to think that she has somehow recovered while writing because when you compare The Woman Who Walked into Doors with Paula Spencer you see that Paula Spencer has somehow overcome her problems in the second book.

RD: Oh, yes. One of the reasons why Paula Spencer is in reasonably good shape is that she has given up drinking. However, it is a huge preoccupation right through the book; she can tell you to the minute when she last had a drink.

BGT: Yes and she is counting the days that she does not take alcohol: a proper habit of alcoholics.

$\mathrm{RD}$ : Oh, yes, but she is also counting money which is a healthy thing, funnily. I always feel the woman, Paula Spencer, is my Celtic Tiger. It's not about the excesses of the money that's in the country; it's about somebody who used to have no money whatsoever. Now she is at a point in her life where she can put bits aside to buy things, say, a computer for her son, a record player or a $\mathrm{CD}$ player for herself, an occasional CD. She has a bit of money in her pocket where there used to be none. That is to say, her life is in better shape; but is it because she wrote her first book or is it just because she has given up drinking? I don't know.

BGT: I will come back to this theme of the Celtic Tiger a bit later but before that I would like to address the issue of representation. Your voice is truly important nowadays in Ireland in its denunciation of life experiences which until recently have 
been silenced: domestic violence, ethnic marginalisation, etc. Would you consider yourself as a spokesperson of these silent realities? Do you consider your (male) gender and your (white) ethnicity as an obstacle or rather as an advantage when writing about female issues?

$\mathrm{RD}$ : There is a lot in that question! In fact I think several questions.

\section{BGT: Sorry! [Laughs]}

RD: It's okay. [Laughs] I don't consider myself to be a spokesman for anybody, and that's important: I'm a writer and I write fiction. In The Woman Who Walked into Doors, I wasn't saying this is the life of a lot of women. This is the life of a fictional character and if I started by making it more general the whole thing called fiction wouldn't work. I mean I'm not a spokesperson for anyone. Does my gender make it an advantage to write? Being a man, is it an advantage to write from the point of view of a woman? Possibly not! It is not a disadvantage either. It gives me pause for thought; I have to think more. When I'm writing about middle-aged men, that's no problem to me whatsoever, but I still have to choose the words. They're very important. I have to choose the right words to capture the feeling of ageing, for example. That wouldn't be unique to men, but there are aspects of it that are unique to men as opposed to women. When I'm writing about it, I can dig into my own personal experience to relive it. Again, you have to choose the words. It's what writers do: choose the words and reject the other words. If I was writing about a 20 -year-old man as a 55year-old man, and I am a 55-year-old man, so I should be ready to stop. However, actually choosing the words can be difficult. When writing from the point of view of a 55-year-old woman, I have to think what we have in common and what we don't have in common. I am never going to be menopausal, for example. I'm never going to grieve about no longer being able to have babies. Hair loss is more common; you know, men lose hair, women grow hair. [Smiles] Then, another issue would be: do I make it darkly comic or do I make it tragic? Men in my experience, maybe it's because I have been friendly with the same men since we were children, we tend to look at fifty-eight as a dark comedy. Do women? I don't know - at the moment - today - this morning, I don't know. I would have to think about it. I don't think my male gender is an advantage but it is a challenge, which is a good thing because then you have to think more. I think in the same way that I used to when I was a 20 -year-old but it's a long time ago. However, I don't know what it's like to be a 20 -year-old man today. I have to be very careful. Does that make sense? Just because I lived it back in 1977 doesn't mean it's still valid. A 20-year-old in 2013 would still be biologically a 20 -year-old and actually and probably $95 \%$ of the experience is much the same. However, I'd have to think carefully before I put my final stamp and say "yes, this is finished". The last thing I think you have mentioned was my ethnicity which I have never thought about. I think if there is anything that makes me a writer more than anything else, it's not my nationality but my city where I grew up. I do like being Irish. I'm not sure why but I do like being Irish. I've never lived anywhere else but given that I travelled quite a lot, which I like, I like the place and I like the quality of life - by quality of life I mean, more than anything else the conversation; the words in the air. Dublin particularly; if I hadn't grown up in Dublin, and in my part of Dublin, I wouldn't write in the same way; the characters wouldn't speak in the same way and the narration wouldn't be the same. It's my city - it has had a bigger effect on my life, more than anything else.

BGT: Talking about age, after reading your latest work, the short story collection Bullfighting and your most recent novel Two Pints, it seems to me that you have somehow changed concerns in your focus on gender. Now instead of focusing so much on women you tend to focus on men and the middle age crisis they experience. Is this true?

$\mathrm{RD}$ : Oh, yes of course. I tend to be working at different things at the same time. When I wrote those stories for Bullfighting I didn't sit down and write a collection of short stories about middle-aged men. They were written now and again over a ten-year period. I think I wrote the first one literally a few days after New Year's 
Day in 2000. The one that's called "The Slave" is the first one that I actually wrote, when I found a dead rat in my kitchen; I used it as an inspiration. It's not about me but the rat. The last one I wrote was maybe in 2010 so it's about a ten-year period. While I was writing them sporadically, I also wrote Paula Spencer, and I wrote several books between: I wrote $O h$, Play That Thing and I wrote The Dead Republic. I wrote several plays and couple of screenplays which don't look at middle-aged men so it's not as if I shifted and abandoned one thing and gave over my attention to middle-aged men. Two Pints is a little facebook thing that I do when the mood hits me, when something happens, and when I have the time. And it's just two middle-aged men. But it's not my life's work. The novel I have just finished is about a middle-aged man and while I was writing that I was also writing a script for a musical based on my first book, The Commitments. The same man. $\mathrm{He}$ is a 20 -yearold man in one piece of work and a 48-year-old man, the same man, in the other piece of work. Every day I was writing about the same man except there is a gap of twenty-eight years in his life. Strange. The great thing about being a writer, or one of the great things about being a writer is that one's life experience can be one of the things that you write about: my children growing older, for example, my feeling of redundancy perhaps for a while as a father because I'm not needed in the same way that I used to be. I'm not driving anywhere; I don't need to do things for them anymore and so I feel a bit redundant and it's not a nice feeling. It takes a while for it to feel like independence but you can use it in the same way as you can use your gradual physical decay as material for your writing. You can be quite bitter about it or you can laugh at it.

BGT: Some critics say that the Celtic Tiger brought a crisis of hyper-masculinity in Ireland. Do you agree?

RD: I don't know really. I don't know what it means! Hyper-masculinity? What does that mean? [Laughs] Like bullish behaviour?

\section{BGT: Yes, I guess so.}

RD: Possibly: in financial services, in banking services. "I have more millions than you!"
(Banging his fist on his chest) Yes, maybe, but I have never witnessed it. Certainly I didn't in my circle. No, I don't remember any writers beating their chests saying "fuck you, I earn more than you!" I don't know. And I didn't witness it on the streets. Often on Friday nights in Dublin, there is a level of violence, for example. However, they were doing that in 1970s - 80s and the 90s and probably last night. If you're walking in any city late at night, you'd have to be careful probably. I'm not sure that the economy has anything to do with that; I'm not sure that I have witnessed it in literature. There are always men who seem to want to express themselves by imposing themselves on others, including other men. That would be in part a day-to-day experience in my school when I was a child. When I was a teenager there was nothing whatsoever to do with the state of the Irish economy so either I don't understand the question or I'll have to probably reject the notion. Possibly in financial services you have cocaine-induced boasting. I don't know because I have never taken cocaine so I don't know what happens. I believe it is very common in banking services not just in Ireland but in the UK; probably everywhere where money is exchanged. They probably had a lot of boastfulness and big cars. However, actually, looking back at the Celtic Tiger, the women in big cars were just as noticeable. Different types of cars. Women were defining themselves by material goods as much as men were. That may well be as in traditional places the money might have been earned by men but women were expressing it in much the same way. Since the recession started, attacks on shops have increased, overwhelmingly by young men. It's not because they are hypermasculine, hyper-desperate or lazy because actually in lot of places they earn no more than they would if they had a job because there is plenty of bad work available. They could earn as much on the minimum wage as they would if they plan a robbery. I don't know if we can see these things too much.

BGT: In your foreword to The Deportees, when you refer to the Ireland of the mid1990 s, you state that "[you] went to bed in one country and woke up in a different one". What kind of an experience was the Celtic Tiger period for you? Have you ever felt like 


\section{an outsider in your own country?}

RD: Yes....

\section{BGT: And did it take you long to adapt to the new situation in Ireland?}

RD: There are two questions there, at least. Ireland has changed dramatically several times since I was a child and I suppose everyone's country has, including yours [Turkey] I would imagine. When I was a child, it was overwhelmingly happy; it was deeply conservative. I didn't know that's what it was; I wasn't aware of anything else. I never saw a black person, which is remarkable, living in a city of over a million people. I don't think I ever saw a black person; there were none in my street. My mother, her father came from Wexford which is South. I'm pointing at it here [Pointing the direction with his hand] at South, South East which is now about one and half hour drive, it was four or five hours drive back then. One of her cousins, one aunt in particular, she lived on a farm with no electricity, no running water. This is mid-1960s. Not unusual for some rural parts of Europe, but very unusual for a Western country on the verge of joining the EU, back then. No electricity, no running water, no toilet facilities. I remember bringing, helping to bring the milk to the local creamery on the back of a donkey and cart. It's like a postcard but actually it's part of the economic reality. Ten years later, that was all gone. Now Ireland is more an urban country and the wealth came and Ireland changed then. It's no longer accurate to say it's a Catholic country; the debate now about abortion. In most cases it's quite a reasonable debate. Thirty years ago, you couldn't mention the word abortion. It would have got people upset. They would start screaming and shouting; some people still do, but the majority of people don't. Actually I find the subject quite boring. It's weird. The only time I have ever felt like an outsider in this country was in my late teens when I decided that God didn't exist and I had no interest in religion. I had to be a bit shrill about it for maybe ten years or so. It was unusual enough for somebody to term themselves an atheist and escaping from God and all the trappings of religion; that was actually quite hard. There were assumptions made when I was a teacher that I was never asked to teach religion, but I was often asked to to bring the children up to the local church for some sort of mass. I didn't mind bringing them to the door but I wouldn't go in. First of all, I'd always feel a bit disrespectful of other people's religion. I would happily go into any religious place now as long as it's not expected that I would get down on my knees. I'm quite happy to go with the rhythm of the symbolism of that particular rite if it's a funeral or whatever; I'm quite happy to go there out of respect for whoever's dead. At the time, being religious was almost an existence for everybody but that died out in the 80s. More and more people decided that religion was not their thing. And then it brought out whole issues like the papal abuse, the Magdalene Laundries, etc. The Catholic Church somehow became the enemy in the eyes of all the people. I think people were quite religious ... but now religion is irrelevant, you know. When I got married in the late 80s, my background was Catholic and my wife was Protestant and people kept pointing it out and nowadays they don't even care. It is not interesting; nobody gives a toss really. Nobody really cares. There was a period when I felt just like a bit of an outsider; maybe all young people felt a little like that; but that is part of growing up. It just happened to be circling around religion at that time. Other than that, no; I have always felt very at home here. I think it's one of the reasons why I write the way I do, because I do feel right at home. I do feel very comfortable in this part of the world, in this part of the city and I do feel very comfortable writing about what I consider ordinary experience slightly twisted. I never feel myself secluded in the way I work, in the attic of my house. I work by myself; I need to feel secluded, distant and I start to feel different from everybody else. I'm self employed; I am a plumber or a builder, you know, I work by myself. Not that I regard writing as work; I don't see a spiritual activity as a job.

BGT: I would also like to talk about the migrant characters in your short stories. For instance, I love the short story "The Pram" in The Deportees.

RD: Oh, thank you. The wooden bridge where it finishes up is down there [Pointing his finger]. 


\section{BGT: Really?}

RD: Yes, twenty minute - half an hour walk. If you go down, it's a lovely walk, along the sea. Yes, the pram is still there... [Laughs]

BGT: Do you personally think that the Irish are very conservative about newcomers?

RD: Not really, no.

\section{BGT: Has this notion diminished through time?}

RD: Very much so, because generally I think the newcomers readily soaked into Irish society. If you look behind the counter you might have noticed none of them are Irish, none of them are born Irish. If you're to get all of your information about Ireland and the media over the last five years, you'd have been told three years ago that people behind the counter are no longer here and they all returned to their own countries, but not where there was money, like back to Sweden or Norway. However, actually that's not the case at all. I'm still surprised; they are skilled workers, these particular workers had quite considerable tasks when this place opened then [Referring to the café where this interview took place]. And none of them are Irish. Ten or maybe twenty years ago it would have been noteworthy that people behind the counters are not Irish, but now nobody cares. Somebody comes to the door and they don't have an Irish accent; I'm not even curious of where they come from originally. I was at the time because it was so unusual: particularly the Africans, because visibly obviously they stand out. However, a Polish person comes in and you wouldn't know they were Polish unless they were talking or speaking Polish. However, when an African walks in the door, it is noteworthy because as I said I have never met a black person in Ireland and suddenly in the heart of Dublin there was an African shop and African barbers. It was extraordinary; so I was asking myself "why would they be coming here?" There wasn't hostility. I know that a lot of people who come here, when they are asked for seventeenth time "where do you come from?", they feel as if they're saying, "go back where you came from". I think at first it was genuine curiosity because we were used to Irish people leaving Ireland, as we still are, not people coming to it.
That's to say, I have encountered very little hostility. There has never been, for example, a political party formed along the same way as that extreme party in the UK, the UK Independence Party, or other extreme nationalist parties in the European countries. We don't have a fascist movement. No politicians have ever said they should all go back to where they came from and it would sort the unemployment problem out. Nobody. There are only a very few people who have ever said it so nobody has ever gained any advantage from ever saying it. There just isn't that feeling in this country, "let's get rid of the immigrants"; nobody thinks that. Even though nobody likes Roma people begging on the streets, I have never heard anybody saying I wish we sent them back them to Romania. It's just one of these things.

BGT: I would like to go back to "The Pram", the wicked female character I may call...

RD: O'Reilly.

BGT: O'Reilly, yes. She is from the upper class...

RD: No, she is not really.

\section{BGT: No? But they were quite rich.}

RD: She'd be a real Tiger; she'd be a Tiger phenomenon. Perhaps she is a bit interesting because she is a woman. Nobody has told her about hyper-masculinity and she is a hypermasculine woman, in a way. Not butch and not a lesbian but she has an inflated notion of herself. She'd be middle class, not upper class. However she is riding that crest of the Tiger and making more money than she should. She has got a big car and the rest of it and she treats that young woman [the Polish childminder of her children] very, very badly. However if that young woman was Irish, she'd treat her equally badly. It's nothing to do with it. That's the nature of that particular character, at that particular point.

BGT: There are not any upper class female characters in your work. Why?

RD: I don't know any. I don't know what upper class is exactly. I have been in a few homes because I am an internationally-known writer, 
so there have been occasions when I have been invited into these homes otherwise I'd have never gone. I don't know how I feel by upper class but by upper-middle class we mean people with a lot of money. I have an acquaintance of some people but I don't know the trappings. I didn't have access. My children went to state schools. We have our own car, seven years old. We have no interest in cars. I don't understand cars. For example, I don't know why a man or a woman would buy a particular car. Women buy a particular type of car; men buy a particular type of car. It's about status. I have been asked what would a 50-yearold man buy to try to prove that he is a 35-yearold man or what would a woman buy to try to prove what she is interested in. I don't know and I have no interest in it. I don't know the significance of furniture. I'm not being dismissive that there have been some brilliant books that do capture that world quite well but I don't know the trappings of that world. I don't have any interest in it and I don't know anybody intimately in that world.

BGT: I would like to ask a couple of questions about The Last Roundup Trilogy, especially about Miss O'Shea. I think she is ignored by many critics in terms of her vitality in Henry Smart's life...

RD: Yes...

BGT: How would you clarify her significance in the story apart from being Henry Smart's primary school teacher?

RD: She is the love of his life, isn't she, literally? Either her presence or her absence is the big thing from the time he meets her until the time he dies. So she is depicted in a romantic sense, as the love of his life.

BGT: You portray Miss O'Shea as a rather independent/dominant female figure but she keeps following Henry. I just couldn't understand why...

RD: Miss O'Shea is trying to find Henry. He is lost but he is trying to find her as well towards the end of The Last Roundup. They both tried to find each other. They could have succeeded, sadly, but then she is dead. It's not a case that she is running after him because he is running after her as well. He had to leave, remember in the end of The Star Called Henry; it's a tactful thing, he had to get out of Ireland; she was in jail so he left first. Therefore, she looks for him and he looks for her. I know people often find their love story quite frustrating but she is simply the love of his life and as is often the case with people: they push the ones they shouldn't push and often they push them away, instead of clutching onto them. They both learn, if you like, very late in their lives who it was they should have been sharing their lives with but that's not their nature. They are both slightly mad. I wasn't aware of what you said as I don't actually read the critics so, I'll take your word for it. [Laughs]

BGT: I also really like the Granny figure, who is a bookworm, reading books all the time.

RD: Yes, yes.... [Smiles]

BGT: I would also like to ask what's your favourite female fictional character in your work?

$\mathrm{RD}$ : My favourite?

BGT: Yes...

RD: Oh, Paula!

\section{BGT: Why?}

RD: Paula was the hardest to achieve. I spent two years writing The Woman Who Walked into Doors. Not a particularly long time to write a novel; it's not a long book. Very little of what I wrote in the first year is in the book ... and I write Monday to Friday, so there are a lot words, very little of it is in the finished book. It was very vague, so in a way, I was trying to get to know her. It was the first year after I'd given up teaching because I was writing full time. During the second year, I began to know her and it began to flow. However, the only way I could get to know her was to go into myself, really, and start thinking about her feelings, about her children. That was that. Then I would put my experience of physical pain, I would use that and then change it. I began to get to know her a bit. I gave the geography of my own childhood; so where she grew up, I grew up. She meets her husband in the dance hall and they are walking home together; that would have been the route I would have taken so I began to visualize it myself. I began to see the 
clothes that would have been worn by everybody including myself in 1974 . The music was very important as well; how we do associate individual pieces of music with the times in our lives. We can visualize and we can smell things, even taste things, if we can associate with the piece of music. I'm not sure if it's still the case because there is such a glut of music these days whereas at the time there were limited opportunities to hear music. You would need to buy music for that matter. People tended to know a song better because they had played it again and again, again and again. Whereas now, it's just a constant flow: you know a song is on the radio for only one day a year nowadays whereas in the summer of 1976 you would have heard only ten songs all the way through that summer. In a way, that's how I have got to know Paula's character. The truth is, I suppose I came back to ten years later. I'll be quite open to the notion of coming back to it again some time.

BGT: I believe you have various favourite writers... What is your favourite female character of other writers?

RD: Good question ... There are a few that spring to mind. There are the barmaids in the "Sirens" chapter of Ulysses by James Joyce. I think they are really, really great. They are brilliant. I can see why in the 1920s the book was banned; why conservative Ireland would have been terrified of these characters because they are very, very sexual. The notion that there were women like this in Ireland would have been a bit frightening for the people like that. They are brilliant; they are really, really great. At the moment ... I can't. It's one of those questions I really need to think about it because I really can't think of anybody. Does it have to be a male writer?

BGT: No, it can be anybody but a female fictional character that you like.

RD: I love The House of Mirth by Edith Wharton. The central character she has, she is fantastic; she is a brilliant, brilliant character. I really like that one.

\section{BGT: Why?}

RD: She's tragic; she's tragic...
BGT: I would like to ask a question regarding Joyce, now that you mentioned him. In an interview with Caramine White, she states that you do not like writers like James Joyce because "[they write] to show off [their] brain[s]" (White 2001: 162), but when I am particularly thinking of Joyce's Dubliners and The Portrait, I also remember Paddy Clarke and Bullfighting, in a way. How do these works influence your writing in terms of their critique of the social and spiritual paralysis in Ireland? Do you think that they have influenced your writing?

RD: I don't know how. I don't know how books influence other books. I read The Portrait of the Artist when I was eighteen. Well, I know that because I was actually working in The Irish Times as a copy boy. Before email, a copy boy was given pieces of paper and told to deliver them to other parts of the city or to the other parts of the building. I used to buy a book to read with my wages and one of them was The Portrait of the Artist, which I carried around with me as I read it. I was eighteen; in 1992 I was writing Paddy Clarke and then I would have been thirty-four so a sixteen year gap, if my maths are right... I wasn't thinking of The Portrait of the Artist when I wrote the first chapters. I was pointed out by some critics for making similarities which are there to be seen, but I wasn't consciously doing it. I don't know if I'm unconsciously doing it. I admired Joyce's Dubliners hugely. It's magnificent and Portrait of the Artist is great. However if I do have criticisms, it's of the later two books. I personally think that Ulysses would be a better book if there was less of it. Unlike quite a lot of people, I find Stephen as a character tremendously irritating but if that's deliberate, grand. I did half-jokingly say that Ulysses could have done with a good edit. I was saying it half-joking; it was taken out of context and became a headline that "Doyle had criticised Joyce". However, if somebody said "would you be happier if Ulysses was edited?" I would have said no. It is the book it is. No more than if somebody said if I'd be happy to have the opportunity to rewrite a passage of the book that you didn't already undertake. No. It is what it is so I think my feelings about Joyce are 
ultimately positive. I think the problem is the Joyce industry. Do I want to put academics out of work? No, I don't really. When you got books written about Joycean scholars, there is something weird about that. I think Beckett is going the same way and probably John McGahern will end up the same. When the academics, forgive me, take ownership of a writer, it makes it hard for ordinary people because they feel intimidated. That's the reality of it, I think. I'm not sure if I'm answering your question.

BGT: Yes, thank you, and do you think that there is a sense of literary comradeship when you think about your contemporaries in Ireland?

RD: Yes, I suppose so. It's as if you're playing with the football team and you're meeting the same eleven men everyday; not every day perhaps, but you're meeting them twice a week, once for training, once for a match. You're going to like five and you're going to tolerate five or so but at least one of them is going to drive you mad. I suppose eleven writers in a room ... a football team, they are much the same world. In a way, I'm drawn to the company of some not because they are great writers but because I enjoy the company. I avoid others not because they are not great writers; it's because I have nothing in common with them. It's so simple; it's the same as everything else. I do always feel a certain fellow feeling. When Kevin Barry won the Impac award a few weeks ago, I was delighted because personally I love his work and I like him. It's as simple as that. If Kevin Barry were a footballer and scored a goal, I would be delighted because it's about football and I like him so it's much less the same thing. If I am to speak on behalf of myself, I don't pay that much attention. I read the work and try to read as much as I can. There are a lot of the newer writers around that I haven't got round to yet but I know that I might read them, during my holidays now. I might be able to read some of those that I have neglected. I always try to keep up to date and I always wish everybody well personally; if I hear they are shortlisted or longlisted or whatever that their books are selling well, I'm always quite happy with that.
BGT: Do you find any similarities in your work and in their work?

RD: Not particularly, but I don't look for them. I'm very much on my own. I have met writers who are often very aware what's going on in the world of publishing and know who has got a contract and who is going where, to what festival. However, I'm often a bit baffled by that and it doesn't really interest me.

BGT: I would like to ask something about the filmic adaptations of your work... Do you think your work loses something when it jumps to the screen or do you find it useful?

RD: Useful is never a word I would use. Inevitably a novel loses something when it becomes interpreted ... It's a different experience. For example, Colm Meaney plays the father in The Snapper. He is magnificent; he is just brilliant so you get that. You get different timing, it's a different energy to the process. It's an entirely different experience. If you are lucky, one will match nicely with the other - if you're lucky. I was involved in the writing of all three screenplays so I was doubly lucky and I think it worked out quite well. With The Commitments, the challenge of the novel was to try to put the music on the paper. The advantage of the film is that it can be heard and seen at the same time so that's the advantage there. However, you lose the point of reading with the music because I think the part of the success of The Commitments as a novel is way the music is presented on the page. It's fun: and the drum beats and the bass lines and the rest of it...; whereas in the film you get it so, you gain things and you lose things because they are entirely different experiences. It is always a gamble. So far, luckily, I have been involved in four adaptations. I suppose, there have been some failures along the way that were never made. So far, I'd be quite happy to say "yes, let's go, do some work" so, I'm lucky in that regard. I' $m$ not in the position to answer ... if that had been the question, as far as I have never had a book that I considered destroyed by a lousy film. I have never been in a position to see a short minor story become a film, a big film. Lots of stories I didn't care because I just don't think it would have worked. I have been lucky. I'm quite content with the both experiences. 
BGT: Apart from novels, you have written screenplays, plays, children's books and short stories. In which literary genre do you feel more comfortable?

RD: Fiction.

\section{BGT: Why?}

RD: You're not dependent on the economic circumstances. You're not dependent on timing, availability of actors, and availability of music. You are not dependent on the enthusiasm of other people involved. While you are writing you're very much in control of your own work, and the challenge is to be in your own complete world. For example, if you're writing a script for other people, that would require dependence. I'm seeing that first hand at the moment because I'm involved in a musical that's going to open in London and later in Europe. I wrote the script and now I'm seeing a set inspired by the script being built. I'm seeing a cast being chosen and I'm seeing other people. I'm not involved in these things because I was purely involved in the words. There were other people building the house, so to speak, on the top of my foundation. Now with the novel, you build the foundation but you also build the house so it's much more challenging, much more engrossing. Obviously, the gamble is you spend ten years of your life doing this, and nobody cares; that's the gamble. If I had pulled back on one it would be that. You are not dependent on the whims of a producer. I have been in meetings where there is this huge promise that they get back to you on Tuesday, but they don't specify what Tuesday and you're still waiting every Tuesday for the rest of your life. The phone call never comes. That's quite common. It's not when you are writing a novel. Their reaction to it is different then. I stopped working on a new book [The Guts] finally last October and that's coming out in August. I haven't worked on a new novel yet, but I'm beginning to feel a bit itchy. I never feel that I have really worked alone; but I'm incredibly busy. I never feel like I'm really working unless I' $m$ also working on something else.

\section{BGT: And what is it going to be about?}

$\mathrm{RD}$ : The new one? The book that is coming out? [Referring to The Guts]
BGT: Yes.

RD: Jimmy Rabitte as a middle-aged man. A year in his life: he has health issues, he has cancer but he survives that. It's about reacquainting himself with things like friendship and other aspects of his life.

BGT: I would like to ask one last question: I have been reading theoretical material for my PhD thesis recently. In Emerging Voices: Women in Contemporary Irish Society, Pat O'Connor (1998) claims that the economic boom in Ireland had affected the lives of women more than men. Now after fifteen years, in the Post-Celtic Tiger period, how would you characterise the situation of women in Ireland?

RD: It's all over the world. I think women by and large are more self confident than they used to be; more assertive; even though they are not particularly well-represented in politics. I suspect in part because they don't want to be. They are not interested in politics as a life. And it's often because they have children, so they can't do it. That might be one element of it. When political adversarial democracy is concerned, you get two sides shouting at each other across the room. In the British and also in American model, which we have, there are the democrats, the republicans, conservative, labour. I don't know if you have the same in your own country but that shouting across the room at each other; women just don't want to be involved and some men don't want to be involved. It comes across as being quite childish and silly. I think that the women don't want to be involved. I think women are more in their bodies and in themselves; they are a very assertive sex and that wouldn't have been the case when I was a young man. The women's use of the language - a as evident on facebook and as evident on my ear, middle-aged men hearing the vulgar language of a young woman, jars a bit - they can be very, very rude, really rude: that's to my ears. However, at the same time I can see it as a positive thing because they are standing up to men in terms of language. I think they are also brutal to each other. There is one word in particular which no man of my generation would ever use no matter how angry they were, they would never ever use it to describe a woman. One word. But I have heard 
it and I have heard women use it quite casually. It's shocking. It will always be a shock!

BGT: Do you think Paula would be like this, if you were writing about her today?

RD: Paula would never use that word. She would use the word but she'd use it very, very sparingly and she would never use it to describe another woman. Her daughter might, her granddaughter might eventually but Paula never would. These are how things change.
BGT: Okay, I think I have asked lots of questions!

RD: I think you probably have a lot there.

BGT: Thank you very much for such a wonderful interview, which has been truly inspiring and will be very helpful for my research.

RD: You are very welcome.

Clontarf / Dublin $24^{\text {th }}$ June 2013

Received 10th Oct 2013 Last version 1st November 2013

Burcu Gülüm Tekin earned her degree in English at the University of Istanbul, Turkey (Department of American Culture and Literature) and she later obtained an MA diploma at the University of Granada, Spain (Department of English Language and Literature) with an MA Thesis on the representation of female characters in James Joyce's work. She is currently conducting her $\mathrm{PhD}$ at the University of Granada on Roddy Doyle's work, by particularly focusing on his portrayal of women, especially mothers. She has presented papers related to Doyle's work in various conferences (i.e. EFACIS, AEDEI and the New Voices Conference). 